\title{
'An Ever Closer Union Among the Peoples of Europe': Union Citizenship, Democracy, Rights and the Enfranchisement of Second Country Nationals
}

\author{
Richard Bellamy
}

This Initiative is to be welcomed if only for opening up the debate and prompting the discussion here - which I have found most instructive. This is an important issue that - with certain honourable exceptions, among them the earlier participants in this useful dialogue - has hitherto not received much academic or political attention, yet resonates with many EU citizens. To give just one anecdotal example, last year UCL conducted two focus groups among EU citizens from other member states resident in London and the issue of national voting rights proved to be of far more concern to them than votes for the European Parliament. Though not a scientific survey, it expresses in certain respects a key feature of the very idea of Union citizenship which, as a political scientist, I find can be lost in the predominantly legal analysis of this topic: namely, the reliance of citizenship rights, including those associated with Union citizenship, on politics in general and the state - in this case the member states - in particular. It is this political context that makes voting rights such an essential part of citizenship, yet one, given the complexities and peculiarities of the EU's political system, that raises a number of difficulties in the European context.

There is a growing tendency to see citizenship as simply the artefact of legal rights. This trend is especially prevalent in accounts of Union citizenship, where the key actor has been the Court of Justice of the European Union (CJEU) and the majority of analyses come from legal scholars. Yet, any legal system has to be understood within the context of the wider political system of which it forms a part and on which it ultimately depends. Not only are laws both the product of and administered and made reality through political processes, but also courts belong to that political apparatus and are themselves political actors, whose mode of adjudication and the degree to which their judgements will be followed reflect the character and capacity of the political institutions within which they are embedded. To the extent that we wish the law and those responsible for its administration to have essential 
democratic qualities - not least in treating all subject to them as political equals, whose interests deserve to be given equal consideration, with the laws applying equally to all -it is important that the law and the rights it embodies should be part and parcel of a democratic polity. It is for this reason that political rights are the defining attribute of citizenship. They form the 'right of rights' since they provide the means whereby citizens can ultimately enact and uphold - both directly and indirectly - all their other rights and assure they have the democratic virtues of showing them equal concern and respect with other citizens. In sum, the very features associated with the rule of law arise from the process of democratization and its accompanying effects on the legal system. It will be objected that rights serve as constraints on democracy and 'majority tyranny'. However, this slogan proves empirically mistaken and overlooks the obvious fact that the main danger to rights comes from minority rule. Democracy has been instrumentally promotive of rights precisely because it obliges rulers to be responsive to as many of the ruled as possible. In so doing, it forces politicians to appeal as far as possible to interests and ideals that are equally and widely shared rather than simply to the narrow sectional interests and ideals of privileged minorities. At the same time, the democratic process engages citizens in reciprocal relations with each other. By endorsing the public polices needed to promote rights -such as a criminal and penal system, health care, schools, pensions, social security and so on - they also sign up to the correlative duties needed to sustain these policies, such as paying taxes.

This argument might seem to lead inexorably to support for the Initiative. Yet, that moves too fast. For, as I noted, the EU political system is notoriously complex and renders the relationship between citizenship and political rights more complicated as a result. European citizenship is accessed through national citizenship which, as the Treaty notes, it is designed to be 'additional to' rather than to 'replace'. This position is consistent with the EU's declared ambition to promote 'an ever closer union among the peoples of Europe' rather than to create a 'European people'. Accordingly, Union citizenship does not so much create access to EU level goods and services as ensure that its possessors are not discriminated against on grounds of nationality when they move to another member state. So conceived, Union citizenship serves to promote mutual respect between the citizens of the different member states by making them all potential citizens or dual citizens of all the other member states should they move to any one of them, at least so far as the four freedoms that are central to the EU are concerned. However, for this mutual respect to operate, it is important that Union citizenship does not undermine the democratic systems of the member states on which 
it is parasitic, and which are needed to deliver those rights agreed upon between them at the EU level. Moreover, two of the main channels of political representation within the EU's own political system - namely, national parliaments and the European Council - are explicitly based on member state citizenship, while even the supposedly direct channel of the European Parliament is based on constituencies designed to give adequate representation to each member state, with elections largely reflecting domestic concerns. So it is important that citizens should be represented through these channels, but not be doubly represented and only to the extent they can commit their representatives to pursuing sustainable policies that show equal recognition to the peoples of Europe.

Two concerns need to be addressed as a result of this multilevel arrangement, therefore, when considering the acquisition of national voting rights in another member state. It must be consistent with:

1). those exercising these rights regarding the national laws as applying equally to all and undertaking the reciprocal obligations needed to sustain the public policies on which the continued enjoyment of rights by all citizens within the member state depend, and

2). the mutual recognition of the citizenship regimes of all member states and their consequent equal representation within the EU's political system.

David Owen's fifth option in his contribution more or less meets these conditions, if read alongside the caveats noted by Rainer Bauböck in his intervention. Thus, all 'second country nationals' (SCNs) should have a fair opportunity of acquiring nationality and hence voting rights in another member state after a minimal period of residence, while all SCNs who do not have nationality in their member state of residence should be eligible to vote in national elections of their member state of nationality. Meanwhile, though dual citizenship should be possible, its holders should only be able to exercise national voting rights in one country. This formula does constrain to some degree member state autonomy over citizenship rules, but only to a minimal degree in ways that in many respects preserve its integrity. On the one hand, it seeks to ensure that those who do vote in national elections are committed to the obligations needed to promote rights equally for all, on the other hand it ensures that there is no double voting for elections that impact on EU policies, so that all are treated equally. It might be argued that naturalisation should not be necessary. Certainly, I can see a case for those within the European sphere to be exempted from citizenship tests, with naturalisation automatic should they so choose. But the choice needs to 
be a considered one that involves a commitment to the long term interests of the polity if voters are not to engage in rent seeking or free-riding behaviour of a kind that would undermine rights.

In remarking that 'Union citizenship is destined to be the fundamental status of nationals of the member states' the CJEU has made it sound as if this new legal status represents the 'right of rights', and at least one contributor to this debate - Dimity Kochenov - has read it in this way. But this judicial hyperbole ignores the extent to which these very rights rest on the underlying obligations that follow from the exercise of democratic citizenship within the member states. As such, national citizenship necessarily continues to provide the fundamental status of Union citizens. However, as the Court's rhetorical formula continues, Union citizenship does have a key role in 'enabling those who find themselves in the same situation to enjoy the same treatment in law irrespective of their nationality, subject to the exceptions as are expressly provided for.' What I have suggested above is that the 'same treatment' must respect reciprocity between citizens within and between the member states, and that the proposed limits on access to and the exercise of national voting rights are among those exceptions that should be 'expressly provided for' within a political organisation committed to the 'ever closer Union of (democratic) peoples'. As such, the Initiative raises a key issue but proposes a misguided solution, at odds with the very nature of the EU.

Open Access This chapter is licensed under the terms of the Creative Commons Attribution 4.0 International License (http://creativecommons.org/licenses/by/4.0/), which permits use, sharing, adaptation, distribution and reproduction in any medium or format, as long as you give appropriate credit to the original author(s) and the source, provide a link to the Creative Commons license and indicate if changes were made.

The images or other third party material in this chapter are included in the chapter's Creative Commons license, unless indicated otherwise in a credit line to the material. If material is not included in the chapter's Creative Commons license and your intended use is not permitted by statutory regulation or exceeds the permitted use, you will need to obtain permission directly from the copyright holder. 